\title{
Kesilapan Penggunaan Kata Kerja dalam Kalangan Pelajar Melayu Ketika Menstruktur Ayat dalam Penulisan Bahasa Sepanyol
}

\author{
Error of Usage of Spanish Verbs in Writing Treatises Malay Students When \\ Structuring Sentences
}

\author{
Mariyati Haji Mohd Nor ${ }^{1}$, Norhana Md. Salleh ${ }^{1} \&$ Hasrina Baharum $^{2}$ \\ ${ }^{1}$ Pusat Bahasa dan Pengajian Umum, Universiti Pendidikan Sultan Idris \\ 35900 Tanjung Malim, Perak \\ ${ }^{2}$ Fakulti Bahasa dan Komunikasi, Universiti Pendidikan Sultan Idris \\ 35900 Tanjung Malim, Perak \\ e-mail: mariyati@fbk.upsi.edu.my
}

\begin{abstract}
Abstrak
Dalam mempelajari bahasa asing seperti bahasa Sepanyol, pelajar sering kali melakukan kesilapan sama ada dari aspek fonologi, morfologi, sintaksis dan semantik. Kesilapan yang berlaku dipengaruhi oleh banyak aspek seperti pengaruh bahasa ibunda, bahasa kedua pelajar, perbezaan ciri linguistik yang terdapat pada bahasa sasaran dan bahasa ibunda pelajar dan sebagainya. Aspek kesilapan yang menjadi fokus dalam kajian ini adalah kata kerja bahasa Sepanyol yang merangkumi pembentukan dan penggunaanya dalam ayat. Pelajar sering kali keliru dengan bentuk konjugasi kata kerja yang pelbagai berdasarkan subjek dan kala, melakukan penambahan kata kerja yang tidak perlu, mengurangkan kata kerja yang perlu, pemilihan kata kerja yang salah dan melakukan terjemahan yang tidak tepat. Oleh yang demikian, kajian ini dilakukan untuk mengenal pasti jenis kesilapan dalam penggunaan kata kerja oleh pelajar Melayu dan menentukan punca kesalahan dan kesilapan yang dilakukan. Bagi mencapai objektif kajian ini, penyelidik menggunakan teori analisis kesilapan oleh Dulay, Burt dan Krashen (1982). Sampel kajian adalah terdiri daripada 50 orang pelajar UPSI yang mempelajari bahasa Sepanyol pada tahap satu iaitu tahap paling asas. Hasil kajian mendapati majoriti responden membuat kesalahan disebabkan struktur ayat bahasa Sepanyol yang berbeza dengan struktur ayat bahasa Melayu, pengaruh daripada bahasa ibunda pelajar tidak dapat dielakkan dan berlaku juga pengaruh daripada bahasa kedua iaitu bahasa Inggeris. Dengan itu, penyelidik mengemukakan beberapa pendekatan dan cadangan dalam usaha meningkatkan pengajaran dan pembelajaran bahasa Sepanyol sebagai bahasa asing di Malaysia.
\end{abstract}

Kata kunci kesilapan, kata kerja, penulisan karangan, pelajar Melayu, bahasa Sepanyol

\begin{abstract}
In studying foreign languages such as Spanish, students often make mistakes either in terms of phonology, morphology, syntax and semantics. Errors that occur are influenced by many aspects such as the influence of the mother tongue, the second language, the difference of the linguistic features of the target language and the mother tongue of students and so on. Aspects of errors that became the focus in this study was the use of the Spanish verbs which includes the formation and usage in verse. Students are often confused with other forms of verb conjugation varied by subject and tense, adding a verb that is not necessary, reducing the verb to be, choosing the wrong verb and inaccurate translation. Therefore, this study was conducted to identify the type of error in the usage of the verb by the Malay students and determine the cause of errors and mistakes made. To achieve the objectives of this study, the researchers used the theory of error analysis by Dulay, Burt and Krashen (1982). The samples were made up of 50 students of the university who studied Spanish at the level of one of the most basic level. The study found the majority of respondents making errors due to the structure difference between the verses of Spanish with Malay sentence structure, the unavoidable influence of the students' native language, and it is also the effect of a second language, English. With that, the researchers suggest several approaches and proposals for the improvement of teaching and learning Spanish as a foreign language in Malaysia.
\end{abstract}

Keywords errors, verb, essay writing, Malay students, Spanish language 


\section{PENGENALAN}

Bahasa merupakan alat komunikasi yang paling utama bagi manusia. Bahasa boleh diperolehi secara tidak formal dan formal sama ada di rumah, di sekolah mahupun di universiti. Kebelakangan ini, timbul keperluan untuk menguasai dan mempelajari bahasa yang lain selain daripada bahasa ibunda dan bahasa ketiga atas pelbagai faktor seperti minat, ekonomi, sosial, budaya dan sebagainya. Atas kepentingan itu, pelajar memilih untuk mempelajari bahasa ketiga yang ditawarkan di universiti sebagai nilai tambah dalam kemahiran pelajar. Antara bahasa yang mendapat sambutan dalam kalangan pelajar adalah bahasa Sepanyol (BS). Hal ini adalah kerana BS merupakan bahasa keempat penutur paling ramai dan mempunyai kira-kira 500 juta penutur di seluruh dunia.

Di Malaysia sekarang ini, minat untuk mempelajari dan menguasai bahasa asing semakin meningkat dalam kalangan masyarakat. Ini adalah kerana masyarakat semakin sedar betapa pentingnya untuk menguasai bahasa lain selain bahasa ibunda yang boleh digunakan dalam kehidupan mereka. Bahasa memainkan peranan penting dalam hidup masyarakat dan kelebihan menguasai lebih daripada satu bahasa merupakan sesuatu yang sangat bernilai (Jamian Mohammad, 2000).

\section{LATAR BELAKANG KAJIAN}

Penekanan kepada aspek tatabahasa amatlah penting bagi meningkatkan keberkesanan dalam pengajaran dan pembelajaran bahasa. Bagi mempertingkatkan lagi kemahiran dalam bahasa, pelajar-pelajar yang mempelajari BS sering menghadapi masalah dalam menggunakan kata kerja di dalam ayat yang dihasilkan. Pelajar sering kali melakukan kesilapan dalam menggunakan bentuk konjugasi yang betul, pemilihan kata kerja yang tidak tepat, penambahan yang tidak diperlukan, pengurangan yang tidak sepatutnya berlaku dan penggunaan kala waktu yang bersesuaian dengan ayat yang dibina. Perbezaan yang jelas di antara sistem BS dan bahasa ibunda pelajar iaitu Bahasa Melayu (BM) juga merupakan faktor penyumbang kepada masalah kekeliruan yang dihadapi oleh para pelajar. Hal ini diakui oleh Lado (1957) dengan menyatakan bahawa;

“... those elements which are similar to (the learners) native language will be simple for him, and those elements that are different will be difficult".

Bahasa Sepanyol dipelajari oleh pelajar atas faktor integratif dan instrumental. Faktor integratif merujuk kepada penyebab individu mempelajari bahasa kedua bagi tujuan berinteraksi, mendekati atau memahami komuniti bahasa kedua (Gardner, 1985). Pelajar yang bermotivasi integratif memiliki minat secara semulajadi di dalam komuniti bahasa kedua. Mereka mempelajari bahasa kedua bagi tujuan komunikasi dan memperolehi hubungan yang rapat dengan komuniti dan budaya masyarakat bahasa kedua (Littlewood, 1984 dalam Azlina, 2009). Manakala faktor instrumental adalah berkait dengan keinginan individu untuk memperolehi pengiktirafan sosial atau manfaat ekonomi melalui pengetahuan bahasa asing (Gardner dan Lambert, 1972). Di dalam motivasi instrumental, tujuan individu mempelajari bahasa adalah kerana nilai utilitari semata-mata seperti untuk berjaya di dalam peperiksaan, melanjutkan pelajaran ke luar negara, memenuhi syarat bergraduat di universiti, memohon pekerjaan, memperolehi gaji yang tinggi ketika memohon pekerjaan, memperolehi status sosial yang tinggi dan sebagainya (Azlina, 2009). 
Salah satu aspek yang penting dalam pembelajaran BS adalah nahu atau tatabahasanya. Kesilapan yang berlaku boleh mengakibatkan ayat yang dihasilkan tidak difahami dan seterusnya mesej tidak dapat disampaikan dengan berkesan. Oleh itu, penguasaan tatabahasa amat penting dan penguasaan yang baik dapat membantu pelajar menghasilkan ayat yang betul dan gramatis. BS mempunyai sistem bahasa yang tersendiri yang berbeza dengan bahasa ibunda pelajar di Malaysia iaitu BM. Sebagai bahasa asing, sistem bahasa yang berbeza ini boleh menimbulkan kesulitan kepada seseorang apabila mempelajari BS. Semakin luas perbezaan sistem BS dan bahasa ibunda, semakin sulit untuk pelajar mempelajarinya. Kesilapan dan kesalahan tidak dapat dielakkan sepanjang proses pembelajaran dan bagi memahami masalah yang dihadapi oleh pelajar Melayu di dalam pembelajaran bahasa Sepanyol di dalam kelas, kajian mengenai analisis kesilapan mengenai penggunaan kata kerja bahasa Sepanyol dilakukan. Analisis Kesilapan (AS) merupakan antara analisis penting berkaitan dengan bahasa yang sering dikaitkan dengan pemerolehan bahasa kedua atau bahasa asing. Kajian ini mengaitkan masalah di dalam pembelajaran bahasa dengan melihat jenis-jenis kesilapan yang dilakukan pelajar dan faktor yang menjadi puncanya. Kajian AK timbul pada akhir tahun 1960-an apabila Corder (1967) salah seorang ahli linguistik yang mempopularkan kajian AS telah membuat anjakan paradigma dalam kajian pemerolehan bahasa. Dalam kajian AK, tujuan kajian adalah untuk memperbaiki proses pengajaran bahasa sasaran, tetapi dalam AS, Corder mencadangkan supaya kajian perlu ditekankan kepada proses pembelajaran (Roshidah Hassan, 2010).

Bahasa kedua ialah bahasa yang dikuasai atau dipelajari selepas menguasai sedikit sebanyak sistem bunyi, struktur dan perbendaharaan kata bahasa ibunda. Ini bermaksud seseorang itu telah memperolehi kebiasaan-kebiasaan bahasa yang sudah sebati dengan dirinya. Pembelajaran bahasa kedua sesudah menguasai bahasa ibunda boleh jadi menguntungkan atau sebaliknya menunjukkan satu gangguan. Sesetengah pendapat mengatakan bahawa pembelajaran bahasa kedua ini lebih mudah kerana liku-liku yang dilalui dalam masa pembelajaran bahasa ibunda telah dialami. Ervin-Tripp (1973) pula menegaskan bahawa dalam banyak hal proses pembelajaran bahasa pertama dan bahasa kedua adalah sama. Lagipun pembelajaran bahasa kedua biasanya berlaku dalam situasi formal di mana butir-butir bahan pengajaran telah dirancang dan disesuaikan untuk pelajar. Tidak seperti dalam pembelajaran bahasa ibunda yang berlaku dalam situasi yang tidak formal dan secara tidak sedar, di mana sekali gus seorang kanak-kanak didedahkan dengan bunyi-bunyi bahasa yang mempunyai pelbagai bentuk dan gaya (Azman Wan Chik, 1982).

Kesilapan dan kesalahan dalam proses pembelajaran bahasa kedua dianggap sebagai satu proses yang tidak dapat dielakkan. Dulay, Burt dan Krashen (1982) mengatakan bahawa sebahagian besar pelajar melakukan kesilapan dalam pembelajaran bahasa kedua berpunca daripada gangguan daripada bahasa ibunda. Manakala menurut Corder (1981) pula, kesilapan merupakan variasi sistem yang dilakukan oleh pelajar yang belum mahir dalam peraturan bahasa yang dipelajari (Corder dalam Hazlina Abdul Halim, 2011).

\footnotetext{
“... A mistake is a random performance slip, and can be really self-corrected, whereas an error is a systematic deviation made by leaners who have not yet mastered the rules of the target language..."
}

Kesilapan merupakan suatu elemen yang penting sebagai bukti untuk mengukur pengetahuan dan kemahiran bahasa seseorang. Pengajaran bahasa akan menjadi lebih berkesan jika tenaga pengajar seperti pensyarah, guru bahasa dan sebagainya tahu bahawa strategi pembelajaran yang digunakan oleh pelajar boleh membantu proses pengajaran bahasa tersebut. Dalam pembelajaran bahasa kedua, Corder (1973) mengkategorikan empat kesalahan yang dilakukan oleh pelajar iaitu pengguguran unsur-unsur yang perlu, penambahan unsur yang tidak perlu atau tidak tepat, pemilihan unsur yang tidak tepat dan penyusunan unsur yang salah. Walau bagaimanapun, menurut Corder, kategori-kategori tersebut belum mencukupi untuk menjelaskan kesalahan, lalu beliau menyertakan kesalahan bagi peringkat-peringkat linguistik seperti morfologi, sintaksis dan leksikon. Kesalahan boleh terdiri daripada pelbagai magnitud termasuklah kesalahan fonem, morfem, kata, ayat, malah perenggan (Erdogan, 2005).

Dulay, Burt \& Krashen (1982) mengkelaskan empat kategori kesilapan yang dilakukan iaitu kesilapan pengurangan, kesilapan penambahan, kesilapan pemilihan dan kesilapan penyusunan. Pengkelasan ini juga dikenali sebagai "taksonomi kesilapan”. Pengkaji menggunakan taksonomi kesilapan 
oleh Dulay, Burt \& Krashen dalam kajian ini dan menambahkan jenis kesilapan lain iaitu kesilapan konjugasi dan terjemahan.

Dapatan kajian daripada Azman \& Goh (2010) menunjukkan bahawa masalah utama yang menjadi kesukaran pelajar mempelajari bahasa Arab adalah kerana nahu bahasa Arab. Apabila membincangkan gangguan bahasa ibunda, sesetengah kesalahan berlaku disebabkan gangguan bahasa Arab standard dan sesetengahnya pula berpunca daripada bahasa Arab pasar (Abisamra, 2003). Walaupun dapatan kajian Abisamra (2003) mendapati pelajar melakukan kesalahan disebabkan gangguan bahasa ibunda, namun kesalahan yang paling banyak dilakukan pelajar adalah kerana kesalahan intralingual.

Kajian Hazlina Abdul Halim \& Mohd Azidan (2011) mendapati bahawa pelajar melakukan kesilapan dalam pemerolehan gender gramatikal dalam bahasa Perancis kerana pelajar tidak menyedari betapa pentingnya atribusi gender gramatikal pada kata nama, sifat dan kata penghubung di dalam bahasa Perancis. Pengaruh bahasa pertama dan kedua juga merupakan aspek yang tidak dapat diketepikan dalam pembelajaran bahasa kedua dalam kajian ini.

Radhiah Ismail (2004) dengan kajian beliau mengenai pembelajaran bahasa Sepanyol dari sudut kata ganti nama diri memperlihatkan hasil dapatan kajian iaitu subjek yang terdiri daripada pelajar Melayu telah melakukan kesilapan dalam kelima-lima aspek kata ganti nama diri yang dikaji iaitu aspek padanan, posisi, pengguguran, susunan dan penambahan. Analisis terhadap aspek padanan menujukkan kekerapan kesalahan padanan kata ganti nama diri dengan genus adalah yang paling tinggi dan kesilapan berlaku kerana perbezaan yang ketara antara kedua bahasa dan unsur gender gramatikal yang tidak wujud dalam bahasa ibunda pelajar.

Salina Husain (2010) pula dalam kajiannya mendapati bahawa kebanyakan pelajar melakukan beberapa kesilapan dalam pembelajaran konjugasi kata kerja bahasa Sepanyol disebabkan perbezaan bentuk konjugasi kata kerja seperti kata kerja Ser dan Estar, yang keduanya membawa makna 'akan menjadi', tetapi setelah diterjemahkan ke dalam BM bentuknya sudah bertukar menjadi 'kata pemeri' iaitu 'ialah' atau 'adalah'. Perbezaan yang timbul ini adalah kesan daripada pengaruh BM yang kuat, namun pendekatan TR oleh Sperber dan Wilson (1986) yang dipilih memperlihatkan bahawa kerelevenan adalah penting bagi menggekalkan makna semantik dan pragmatiknya. Hal ini demikian kerana dalam proses penterjemahan kata, makna sebenar perlu dikekalkan supaya mesej yang hendak disampaikan adalah tepat.

\section{METODOLOGI}

\section{Batasan Kajian}

Penyelidik memfokuskan kajian kepada pembelajaran BS sebagai bahasa asing yang dipelajari di Universiti Pendidikan Sultan Idris (UPSI). Skop kajian ini adalah kepada kesilapan penggunaan kata kerja BS dalam karangan oleh pelajar Melayu. Kajian ini akan melihat kesilapan penggunaan kata kerja dari aspek pembentukan konjugasi, penambahan, pengurangan, kesilapan pemilihan bentuk SER dan ESTAR, kala dan terjemahan secara literal daripada bahasa ibunda dan bahasa kedua pelajar. Dalam kajian ini, pengkaji hanya melihat kesilapan kata kerja sahaja yang dilakukan oleh pelajar dalam karangan yang ditulis. Kesilapan lain yang terdapat dalam karangan yang sama tidak akan dilihat dan diambil kira.

\section{Sampel Kajian}

Seramai 50 orang pelajar Melayu dari UPSI di Perak telah dipilih sebagai sampel kajian ini. Mereka terdiri daripada campuran pelajar perempuan dan lelaki iaitu 32 orang pelajar perempuan dan 18 pelajar lelaki. Sampel merupakan pelajar-pelajar pelbagai jurusan kursus pendidikan di UPSI yang berada di semester 1 dan 2. Walaupun mereka daripada jurusan yang berbeza, namun mereka mengikuti kelas BS yang sama tahap iaitu Kursus Bahasa Sepanyol Komunikasi 1, kursus BS yang paling asas sekali. Sampel menggunakan sukatan pelajaran yang sama, buku yang sama dan diajar oleh guru yang sama. Karangan ini ditulis setelah sampel berada pada minggu ke-13 kuliah dan ketika karangan ditulis, pelajar telah didedahkan dengan semua silibus untuk kursus BS komunikasi 1 termasuk kata kerja. Pelajar-pelajar ini 
dipilih berdasarkan persamaan bahasa ibunda iaitu BM, umur dan taraf kecekapan dalam BS. Mereka berumur di antara 19-25 tahun dan berasal dari pelbagai negeri.

\section{DAPATAN DAN PERBINCANGAN}

\section{Analisis Kesilapan Penggunaan Kata Kerja dalam Karangan Pelajar}

\section{Kesilapan dari Segi Bentuk Konjugasi Kata Kerja}

Mengkonjugasikan kata kerja di dalam bahasa Sepanyol adalah cukup sukar dilakukan. Hal ini adalah kerana untuk mengkonjugasikan kata kerja teratur (regular) dan tidak teratur (irregular) di dalam ayat kala kini dan lepas, apa yang seharusnya dilakukan adalah mengetahui subjek yang melakukan perbuatan, hilangkan huruf akhiran pada kata kerja, dan tambahkan huruf akhiran yang disesuaikan dengan subjek. Konjugasi untuk kata kerja teratur dan tidak teratur adalah berbeza. Pelajar sering melakukan kesilapan dalam mengkonjugasikan kata kerja di dalam karangan yang ditulis. Jadual 1 di bawah memperlihatkan kesilapan penggunaan bentuk konjugasi dalam karangan pelajar.

Jadual 1 Kesilapan dari segi bentuk konjugasi kata kerja dan terjemahan ayat dalam bahasa Melayu

\begin{tabular}{|c|c|c|}
\hline $\begin{array}{c}\text { A1 } \\
\text { Sampel } 2\end{array}$ & Kesilapan kata kerja & $\begin{array}{l}\text { La razón por la que estudiar español es porque me } \\
\text { encanta escuchar la canción española. }\end{array}$ \\
\hline $\begin{array}{c}\text { Perenggan } 1 \\
\text { Ayat } 9\end{array}$ & Ayat yang betul & $\begin{array}{l}\text { La razón por la que estudio español es porque me encanta } \\
\text { escuchar la canción española. } \\
\text { "Alasan kenapa saya belajar bahasa Sepanyol adalah } \\
\text { kerana saya suka sangat mendengar lagu dalam bahasa } \\
\text { Sepanyol". }\end{array}$ \\
\hline $\begin{array}{c}\text { A2 } \\
\text { Sampel } 7\end{array}$ & Kesilapan kata kerja & $\begin{array}{l}\text { Mi padre también hablar siempre con ellos y espero que se } \\
\text { dio cuenta de sus errores. }\end{array}$ \\
\hline Ayat 28 & Ayat yang betul & $\begin{array}{l}\text { Mi padre también habla siempre con ellos y espero que se } \\
\text { den cuenta de sus errores. } \\
\text { "Ayah saya juga selalu bercakap dengan mereka dan } \\
\text { saya harap mereka sedar kesilapan mereka". }\end{array}$ \\
\hline
\end{tabular}

Contoh ayat A1-A2 merujuk kepada kesilapan yang dilakukan oleh pelajar dari segi penggunaan kata kerja yang tidak dikonjugasikan berdasarkan subjek iaitu kata kerja estudiar dan hablar. Dalam ayat tersebut subjek atau pelaku bagi A1 adalah 'saya' dan untuk ayat kedua adalah 'ayah saya'. Pelajar seharusnya mengubah kata dasar estudiar dan hablar menjadi estudio yang bermaksud 'saya belajar' dan habla yang bermaksud 'Ayah saya bercakap'.

\section{Kesilapan Penambahan Kata Kerja}

Kesilapan penambahan, menurut Dulay, Burt \& Krashen (1982) adalah hasil dari penggunaan secara berleluasa peraturan tertentu dan mencadangkan kesilapan jenis ini terbahagi kepada dua kategori iaitu 'regularisasi' iaitu kesilapan terlepas pandang, pengecualian dan juga kesilapan mengaplikasikan peraturan pada domain di mana peraturan tersebut tidak sepatutnya diaplikasikan. Kesilapan penambahan kata kerja berlaku apabila pelajar menambah bentuk kata kerja yang lain atau melibatkan sebarang kemasukan elemen kata kerja lain yang tidak perlu di dalam ayat yang dibina. Contoh bentuk penambahan kata kerja yang dilakukan oleh pelajar adalah seperti contoh di dalam jadual di bawah: 
Jadual 2 Kesilapan penambahan kata kerja dan terjemahan ayat dalam bahasa Melayu

\begin{tabular}{ccl}
\hline A3 & Kesilapan kata kerja & Soy es buenas y amable. \\
Sampel 3 \\
$\begin{array}{c}\text { Perenggan 1 } \\
\text { Ayat 4 }\end{array}$ & & \\
\cline { 2 - 3 } A4 & Ayat yang betul & $\begin{array}{l}\text { Soy buena y amable. } \\
\text { "Saya adalah seorang yang baik". }\end{array}$ \\
Sampel 3 & Kesilapan kata kerja & Yo soy tengo ídolo. \\
Perenggan 1 & Ayat yang betul & Tengo ídolo. \\
Ayat 25 & "Saya mempunyai idola". \\
\hline
\end{tabular}

Bagi ayat A3-A4 dalam Jadual 2 di atas, pelajar telah menambah kata kerja yang tidak perlu bersamasama dengan kata kerja yang sudah betul penggunaanya. Penambahan itu menyebabkan ayat yang dibina adalah salah dari segi nahunya. Ayat 3, kata kerja 'es' tidak perlu berada di dalam A3 kerana ianya akan merosakkan maksud ayat yang dibina. Soy "saya adalah" dan es "dia adalah" tidak boleh hadir bersebelahan. Begitu juga dengan A4, Soy "saya adalah" dan tengo "saya mempunyai" juga tidak boleh hadir bersama. Dalam A4, kata kerja tengo adalah tepat dan betul. Penambahan kata kerja soy tidak perlu dan menyebabkan ayat yang dibina salah.

\section{Kesilapan Pengurangan Kata Kerja}

Kasper dan Kallerman dalam Hazlina (2011) menyatakan bahawa kesilapan pengurangan atau omission error dilakukan oleh pelajar pada awal tahap pembelajarannya. Pelajar kerap melakukan pengurangan kepada kata kerja jenis refleksif di mana kata kerja ini perlu hadir bersama dengan kata ganti nama seperti $\boldsymbol{m e}$, te, se, nos, os dan se di hadapan kata kerja. Walau bagaimanapun, pengurangan juga berlaku kepada kata kerja utama dalam sesuatu ayat. Contoh kesilapan pengurangan kata kerja ini boleh dilihat dalam jadual di bawah:

Jadual 3 Kesilapan pengurangan kata kerja dan terjemahan ayat dalam bahasa Melayu

\begin{tabular}{ccl}
\hline A5 & Kesilapan kata kerja & Ella casó joven. \\
Sampel 4 \\
$\begin{array}{c}\text { Perenggan 2 } \\
\text { Ayat 5 }\end{array}$ & Ayat yang betul & $\begin{array}{l}\text { Ella se casó joven. } \\
\text { "Dia berkahwin muda". }\end{array}$ \\
\cline { 2 - 3 } A6 & Kesilapan adjektif & Mi hermano travieso pero bueno. \\
Sampel 21 & Ayat yang betul & Mi hermano es travieso pero bueno. \\
Perenggan 1 & "Adik saya seorang yang nakal tetapi baik". \\
\hline
\end{tabular}

Contoh-contoh di atas merupakan kesilapan pengurangan kata kerja bahasa Sepanyol. A5 merupakan ayat yang menggunakan kata kerja refleksif iaitu kata kerja yang merujuk kepada perbuatan ke atas diri pelaku. Kata kerja ini mesti hadir dengan kata nama seperti $\boldsymbol{m e} \boldsymbol{e}$, $\boldsymbol{e}$, $\boldsymbol{s e}$, nos, os dan se. Namun dalam A5 pelajar telah mengurangkan kata kerja se casó menjadi casó sahaja. Pengkaji mendapati pelajar melakukan kesilapan ini kerana pelajar mengeneralisasikan kata kerja ini seperti kata kerja yang lain bukan refleksif yang hadir tanpa kata nama dihadapannya. Manakala dalam contoh A6 pula, pelajar meninggalkan kata kerja utama iaitu $\boldsymbol{e s}$ dalam ayat yang dibina. Pengkaji berpendapat bahawa pelajar terpengaruh dengan ayat bahasa Melayu (Terjemahan :" adik saya <> nakal tetapi baik". Di dalam bahasa Melayu, kata kerja boleh digugurkan dalam ujaran "adik saya nakal tetapi baik" menyebabkan pelajar mengaplikasikan peraturan yang sama dalam bahasa Sepanyol. 


\section{Kesilapan Pemilihan Kata Kerja SER dan ESTAR (to be)}

Salina Husain (2011) mengatakan antara perbezaan yang sering mengelirukan pelajar bahasa Sepanyol ialah penggunaan kata kerja SER dan ESTAR. Kata kerja SER dan ESTAR dalam bahasa Sepanyol berkongsi makna yang sama iaitu "akan menjadi" tetapi mempunyai pengunaan yang berbeza di dalam ayat. SER dan ESTAR dalam bahasa Melayu , maknanya dirujuk sebagai kata pemeri "ialah" dan "adalah". SER digunakan dalam ayat untuk menerangkan identiti seseorang atau sesuatu benda, pekerjaan, kualiti peribadi, asal usul, warna dan hak milik, manakala kata kerja ESTAR pula digunakan untuk menerangkan tempat atau kedudukan seseorang atau sesuatu benda, keadaan yang berbentuk sementara seperti emosi manusia dan reaksi seseorang. Oleh kerana mempunyai maksud yang sama, pelajar sering mengalami kekeliruan penggunaan kedua kata kerja ini di dalam ayat. Contoh di bawah adalah kesilapan penggunaan kedua bentuk kata kerja ini.

Jadual 4 Kesilapan pemilihan kata kerja SER dan ESTAR (to be) dan terjemahan ayat dalam bahasa Melayu

\begin{tabular}{|c|c|c|}
\hline $\begin{array}{c}\text { A7 } \\
\text { Sampel 8 }\end{array}$ & Kesilapan kata kerja & Estoy muy baja y delgada. \\
\hline $\begin{array}{l}\text { Perenggan } 1 \\
\text { Ayat } 5\end{array}$ & Ayat yang betul & $\begin{array}{l}\text { Soy muy baja y delgada. } \\
\text { "Saya seorang yang rendah dan kurus". }\end{array}$ \\
\hline $\begin{array}{c}\text { A8 } \\
\text { Sampel } 18\end{array}$ & Kesilapan kata kerja & Soy feliz estudias español. \\
\hline $\begin{array}{c}\text { Perenggan } 1 \\
\text { Ayat } 10\end{array}$ & Ayat yang betul & $\begin{array}{l}\text { Estoy feliz estudiar español. } \\
\text { "Saya gembira belajar bahasa Sepanyol". }\end{array}$ \\
\hline
\end{tabular}

A7 merujuk kepada ayat yang sepatutnya menggunakan kata kerja SER kerana ia menggambarkan kualiti peribadi seseorang iaitu rendah dan kurus. Namun pelajar melakukan kesilapan dengan memilih kata kerja ESTAR dalam ayat tersebut. Begitu juga dalam A8, kata adjektif feliz merupakan keadaan emosi yang bersifat sementara dan ianya boleh berubah. Oleh yang demikian, untuk menggambarkan emosi seseorang kata kerja yang tepat adalah ESTAR. Pengkaji mendapati pelajar tidak dapat membezakan penggunaan kedua kata kerja ini dengan baik kerana berkongsi makna yang sama. Kekeliruan ini menyebabkan kesilapan sering kali berlaku.

\section{Kesilapan Pemilihan Kata Kerja yang Lain}

Kesilapan juga berlaku akibat pemilihan kata kerja yang salah dalam menghasilkan sesuatu ayat. Dulay, Burt \& Krashen (1982) mengkelaskan kesilapan yang dilakukan pelajar kepada empat kategori dan antaranya adalah pemilihan. Begitu juga dengan Corder (1981) yang mengatakan bahawa kesilapan pemilihan kerap kali berlaku pada pelajar yang baru mula belajar bahasa yang baharu. Kesilapan pemilihan kata kerja boleh dilihat dalam jadual 5 seperti di bawah:

Jadual 5 Kesilapan pemilihan kata kerja yang lain dan terjemahan ayat dalam bahasa Melayu

\begin{tabular}{ccl}
\hline $\begin{array}{c}\text { A9. } \\
\text { Sampel 13 } \\
\text { Perenggan 2 } \\
\text { Ayat 1 }\end{array}$ & Kesilapan kata kerja & Estoy seis hermanos, cuatro hermanas, dos hermanos. \\
\cline { 2 - 3 } & Ayat yang betul & $\begin{array}{c}\text { Tengo seis hermanos, cuatro hermanas y dos hermanos. } \\
\text { "Saya mempunyai } 6 \text { orang adik beradik, } 4 \text { orang } \\
\text { perempuan dan } 2 \text { orang lelaki". }\end{array}$ \\
$\begin{array}{c}\text { A10. } \\
\text { Sampel 6 } \\
\begin{array}{c}\text { Perenggan 1 } \\
\text { Ayat 22 }\end{array}\end{array}$ & Kesilapan kata kerja & $\begin{array}{l}\text { Que son } 19 \text { años y } 7 \text { años. } \\
\text { Aue tienen } 19 \text { años y } 7 \text { años. } \\
\end{array}$ \\
\end{tabular}


Dalam jadual di atas, pengkaji mendapati ada beberapa kesilapan pemilihan kata kerja yang dilakukan oleh pelajar. Antaranya dalam A9 dan 10 di mana pelajar telah menggunakan kata kerja yang tidak sepatutnya iaitu estoy "akan menjadi" dalam ayat Tengo seis hermanos, cuatro hermanas y dos hermanos "Saya mempunyai 6 orang adik beradik, 4 orang perempuan dan 2 orang lelaki". Kata kerja estoy tidak boleh digunakan kerana membawa maksud berlainan dengan apa yang ingin ditulis pelajar. Begitu juga dengan A10, pelajar memilih kata kerja SER untuk menyatakan umur seseorang sedangkan dalam bahasa Sepanyol untuk menerangkan tentang usia kata kerja tener "mempunyai" digunakan.

\section{Kesilapan Terjemahan Kata Secara Terus}

Kesilapan lain yang dikenalpasti adalah kesilapan dengan menterjemahkan perkataan adjektif secara terus daripada bahasa ibunda kepada BS. Lado (1957) menerangkan tentang kesukaran penutur mempelajari bahasa asing kerana mereka akan cenderung untuk membawa masuk tabiat struktur bahasa ibunda ke dalam bahasa asing yang dipelajari, sekaligus akan menyebabkan berlakunya kekeliruan dan kesilapan. Selain itu, pengaruh daripada bahasa Inggeris juga dapat dilihat dalam ayat pelajar. Sebagai contohnya kesilapan ini boleh dilihat dalam Jadual 7 di bawah.

Jadual 7 Kesilapan terjemahan secara terus dan terjemahan ayat dalam bahasa Melayu

\begin{tabular}{|c|c|c|}
\hline $\begin{array}{c}\text { A11. } \\
\text { Sampel } 32\end{array}$ & Kesilapan kata kerja & Él es 16 años. \\
\hline $\begin{array}{l}\text { Perenggan } 2 \\
\text { Ayat } 5\end{array}$ & Ayat yang betul & $\begin{array}{l}\text { Él tiene } 16 \text { años. } \\
\text { "Dia berumur } 16 \text { tahun". }\end{array}$ \\
\hline $\begin{array}{c}\text { A12 } \\
\text { Sampel } 37\end{array}$ & Kesilapan kata kerja & Ella ya casada. \\
\hline $\begin{array}{c}\text { Perenggan } 2 \\
\text { Ayat } 9\end{array}$ & Ayat yang betul & $\begin{array}{l}\text { Ella ya está casada. } \\
\text { "Dia sudah berkahwin". }\end{array}$ \\
\hline $\begin{array}{c}\text { A13 } \\
\text { Sampel } 35\end{array}$ & Kesilapan kata kerja & Me gusta jugando guitarra. \\
\hline $\begin{array}{l}\text { Perenggan } 2 \\
\text { Ayat } 7\end{array}$ & Ayat yang betul & $\begin{array}{l}\text { Me gusta tocar la guitarra. } \\
\text { "Saya suka bermain gitar". }\end{array}$ \\
\hline
\end{tabular}

Dalam ayat A11 di atas, ayat ditulis oleh pelajar Él es 16 años akibat pengaruh daripada bahasa ibunda pelajar iaitu BM atau daripada bahasa Inggeris yang bermaksud "Dia berumur 16 tahun" atau "He is 16 years old". Namun dalam bahasa Sepanyol untuk menyatakan usia seseorang kata kerja yang digunakan adalah tener "mempunyai" dan bukan kata kerja es. Ayat yang betul adalah Él tiene 16 años "Dia berumur 16 tahun". Kesilapan yang seterusnya adalah meninggalkan kata kerja ESTAR dalam ayat dia sudah berkahwin kerana pengaruh dalam bahasa ibunda yang tidak mempunyai kata kerja to be dalam ayat tersebut. Kesilapan terjemahan juga berlaku dalam AI3, pelajar menggunakan kata kerja jugando "bermain" dalam ayat saya suka bermain gitar, namun dalam bahasa Sepanyol kata kerja yang digunakan untuk bermain gitar adalah tocar bukan jugar. Jugar digunakan untuk segala permainan sukan dan juga games tetapi bukan alatan muzik. Hal ini adalah kerana pelajar menterjemahkan ayat tersebut dalam bahasa Sepanyol tanpa mengetahui bahawa kata kerja yang digunakan adalah tidak tepat.

\section{KESIMPULAN}

Dapatan daripada kajian yang telah dijalankan ke atas karangan pelajar yang ditulis, telah memperlihatkan kesulitan-kesulitan yang dihadapi oleh pelajar-pelajar Melayu berkaitan dengan sistem morfologi BS iaitu kata kerja. Hasil daripada semakan ke atas karangan pelajar, pengkaji mendapati bahawa kesilapan paling banyak dilakukan oleh pelajar adalah dari segi bentuk konjugasi kata kerja. Perubahan bentuk kata kerja 
ini berlainan bagi setiap subjek atau pelaku dan berubah bagi setiap kala (kini, lampau, sedang, hadapan dan sebagainya). Hal ini menyukarkan pelajar. Pelajar seharusnya cuba untuk menguasai formula konjugasi kata kerja seperti yang diajar oleh pensyarah dan ianya dapat membantu pelajar meminimunkan kesilapan yang dilakukan. Pelajar seharusnya peka dengan perbezaan sistem dan struktur kata kerja bahasa Sepanyol dengan bahasa ibunda pelajar. Pelajar tidak sedar bahawa kesilapan yang serupa tidak akan dibuat oleh penutur asal dan kesilapan yang dipandang remeh ini adalah suatu kesilapan yang tidak akan dimaafkan oleh penutur asal (Surridge dalam Hazlina, 2011). Selain itu, kesilapan juga berlaku dari aspek lain seperti penambahan, pengurangan, pemilihan dan terjemahan melibatkan kata kerja. Walau bagaimanapun, kesilapan adalah perkara biasa apabila mempelajari sesuatu yang baharu dan tidak boleh dianggap sebagai elemen yang boleh mematahkan semangat dan motivasi kepada pelajar. Pengaruh bahasa ibunda tidak dinafikan merupakan aspek yang penting dalam pemerolehan bahasa asing. Lado (1957) ada mengatakan bahawa aspek persamaan yang wujud antara bahasa asing iaitu bahasa yang dipelajari pelajar dengan bahasa ibunda pelajar akan membantu pelajar dengan mudah dan aspek perbezaan akan menyukarkan pelajar. Sesuatu bahasa itu amat mudah dipelajari sekiranya kita memahami dengan baik struktur bahasa sasaran dan dengan adanya teknologi sekarang, banyak bantuan pembelajaran yang boleh diperolehi bagi meningkatkan penguasaan pelajar dan ianya tidak lagi tertumpu di dalam kelas semata-mata.

\section{RUJUKAN}

Azlina Seraai. (2009). Orientasi dan motivasi pelajar dalam pembelajaran bahasa Sepanyol, MA Thesis, Universiti Malaya.

Azman Che Mat \& Goh Yin Soon. (2010). Situasi pembelajaran bahasa asing di institusi pengajian tinggi. Perbandingan antara bahasa Arab, bahasa Mandarin dan bahasa Perancis, AJLTHE Vol 12 (2) P.9-20.

Azman Wan Chik. (1982). Trend-trend baru dalam pendidikan bahasa. Kuala Lumpur: Utusan Publication.

Corder, S.P. (1967). The significance of learners`errors. International Review of Applied Linguistics, 5, 161-169.

Corder, S, P. (1981). Error analysis and interlanguage. London: Oxford University Press.

Corder, S, P. (1983). Strategies of Communication. In C. Faerch \& G. Kasper (Eds). Strategies in interlanguage Communication. London: Longman.

Corder, S, P. (1983). Strategies of Communication. In C. Faerch \& G. Kasper (Eds). Strategies in interlanguage Communication. London: Longman.

Dulay, H.C., Burt, M. \& Krashen, S. (1982). Language two. New York: Oxford University Press.

Erdogan, V. (2005). Contribution of error analysis to foreign language teaching. Mersin University Journal of the Faculty of Education. 2, 261-270.

Erwin -Tripp, S.W. (1978). Is second language learning like the first? dlm Second Language Acquisition, E.M. Hatch (ed), Rowley Mass: Newbury House.

Gardner, R. C \& Lambert, W.E. (1972). Attitudes \& motivation in second language learning. Rowley, M.A: Newbury House Publisher.

Hazlina Abdul Halim \& Mohd Azidan Abdul Jabar. (2011). Kesilapan penambahan dan pengurangan pemerolehan gender gramatikal dalam kalangan pelajar bahasa Perancis dlm Lingua 3. Penerbit Universiti Putra Malaysia.

Lado. R. (1957). Language across culture: Applied linguistics for English teachers. Ann Arbor: Chicago of Michigan Press.

Littlewood, W. (1984). Foreign and second language learning. Language acquisition research and its complications for the classroom. Cambrigde: Cambridge University Press.

Mohamad, Jamian. (2000). Analisis kesilapan penggunaan kata kerja dalam bahasa Portugis di kalangan pelajar Universiti Malaya / Jamian bin Mohamad. Masters thesis, Universiti Malaya.

Radhiah Ismail. (2004). Penguasaan kata ganti nama diri bahasa Sepanyol di kalangan pelajar Melayu. MA Thesis, Universiti Malaya.

Roshidah Hassan. (2010). Sistem fonetik dan fonologi bahasa Melayu dan bahasa Perancis. Satu analisis kontrastif dan analisis kesilapan. Kuala Lumpur: Universiti Malaya.

Salina Husain. (2010). Penggunaan konjugasi kata kerja Bahasa Sepanyol dan perbandingannya dengan Bahasa Melayu. Serdang: Universiti Putra Malaysia.

Salina Husain. (2011). Kata kerja Estar dan bandingannya dengan bahasa Melayu dlm Lingua 3. Penerbit Universiti Putra Malaysia.

Surridge, M. (1985). Le genre grammatical des composés en francais. CJL 1985; 30:247-72. 